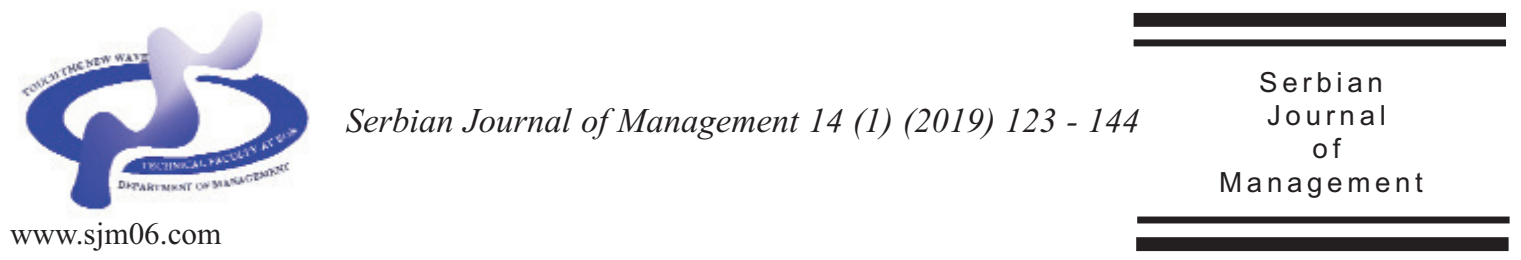

\title{
CLIENT DRIVEN TRADING STRATEGIES: A PRACTICAL MODELING IN THE CONTEXT OF FINANCIAL DERIVATIVES MARKET
}

\author{
Aravind Mohanan Potti* \\ TKM Institute of Management, Affiliated to University of Kerala, \\ Karuvelil P.O, Kollam, Kerala, India-691 505
}

(Received 06 October 2017; accepted 11 July 2018)

\begin{abstract}
Financial derivatives are widely recommended by financial advisors and brokers to hedge the investment position of their clients. But due to the heterogeneity existed between retail investor groups they are not in a position to offer more customized service to their clients. The present study is developed on the basis of a survey conducted among 200 experts working in various broking firms. The opinions, so collected from experts were evaluated using different statistical measures in order to select some suitable strategies. Statistical tools like MANOVA, Chi-square, paired sample ' $t$ ' test, etc. were used to analyze the viability of the expert recommendations. Based on this empirical analysis some strategies were identified for derivative trading and a theoretical model was formulated for dealing with diversified group of retail investors.
\end{abstract}

Keywords: role of stakeholders, managing client traffic, client driven business model

\section{INTRODUCTION}

Wide ranges of financial instruments are available in an emerging market like India. Considering multiple investment alternatives the ordinary investors may not be in a position to choose the right investment option. This situation imposes them to seek the service of an investment advisor to choose a suitable investment decision. While observing the Indian derivative market; the market participants, especially Low Net worth Individuals (LNI) are highly resorting to the advice of their depository participants (DP) for their investment modeling. The diversified background of investors also enhanced the complexity of the advisor's job. Because the investment strategy opted

\footnotetext{
* Corresponding author: aravind.1551@gmail.com
}

DOI: $10.5937 /$ sjm14-15264 
for one client may not be suitable for another in any context. From another dimension the ordinary investors are encouraged to trade with derivatives; because intermediaries like broking firms can generate maximum revenue by way of broking fee. In the derivatives market with a modest sum the clients can enter into a contract for a huge volume. Thus the broking fees from financial derivative contracts are comparatively multiples than that of broking fee from cash market. Due to this the depository participants will advise their clients to trade with derivatives even if the client is lacking adequate knowledge on its operational mechanism. This has created a need for having a trading structure to address the need of both ends. This work intended to design some viable strategies for trading with financial derivatives which will be mutually benefitted to ordinary investors as well as the financial advisors.

\section{REVIEW OF LITERATURE}

The review of literature is structured in four different dimensions. They are major factors determining the investors trading decision with derivatives, the role of a broking firm in shaping investment behavior, investor's satisfaction with services from broking houses and their opinion on present online trading platform.

Allen and Santamero (1998) argue that with the introduction of futures and options a new avenue for financial intermediation has opened. Earlier the financial intermediation was based on asymmetric information. In the present scenario information asymmetry has declined, but the role of intermediation has increased. So the intermediaries like broking houses have to offer more sophisticated service to their clients by bringing a higher level of customization in service.

Ravichandran (2008) in his study identified that most of the investors in derivative trading are following the ideas given by the financial experts and tips given in the newspaper to reduce their risk. So the investors should always keep informed about the market changes that likely address in the near future.

Tripathy (2014) in his research says that investors mainly use their own research or broker's advice to invest in derivatives. The reasons for not investing in derivatives are lack of knowledge and complex understanding about derivatives. These study results were derived by conducting a survey among 100 respondents in the Delhi/NCR Region.

In another study Vignesh and Lawrence (2016) argue that the knowledge level of respondents in derivative market and product is not up to the mark, most of the retail investors are not even aware of derivatives. This is the main reason that most of the investors are not trading in derivatives products. The stock broking firms should help the retail investors by giving proper guidance, for trading with derivative products.

In the words of Hatzakis et al. (2010) the traditional role of security broking firms has changed. According to him traditional broking houses charging fixed commissions evolved or were replaced by diverse organizations offering full service, discount, and online trading channels, as well as research and investment advisory services.

Until the midst of the 1990's the number of brokers in the Indian market was low and competition among them was limited. As the demutualized exchanges appeared on the exchange landscape, the entry barrier for the 
brokers was lowered. As a result, competition among brokers intensified, which led to a substantial fall in the brokerage fees; says Mohanthy (2011).

Dhananjhay (2014) brought an expressive view on the development of the broking industry in India. The work exclaims that the brokerage industry is witnessing rapid growth in terms of business, distribution \& network and enterprise value. The majority of stock broking companies is focusing on value-added services. Over the last two decades, the Indian Capital Market has undergone significant changes, reflecting the increasing role of the private sector and the increasing globalization and integration of international financial activity.

Kaur and Singh (2015) examine the role of brokers to induce investment in the Indian stock market. By evaluating the response from 100 brokers they arrive at a conclusion that the investors are hesitating to invest in the stock market due to lack of knowledge and confidence. They suggest that the quality ready to use information will really help to enhance the number of online clients. In another research Kavitha (2015) divulges that more awareness needs to be created among ordinary investors to ensure their participation in the stock market. Shafi (2014) intended to analyze the factors which influencing individual investor's behavior across various countries. In the above study it found that advice or recommendation from the broker, family members, friends and stock holder can play a vital role in shaping their behavior.

Rajkumar (2015) looks into the relevance of stock broking industry in the capital market. This work examines the history of broking industry, service and products dealt with them and recent challenges. He says that many small time investors are waiting to enter the stock market and test the waters. Since most of them will be first time investors, they will require knowledge about the market and also details of the companies which can be provided by the brokers, for a fee and if the small investor has given good advice then he/she may introduce many more clients to the broker who in turn may earn more, thereby making the situation a winwin one for the investor and also the broker.

In the words of Wood and Zaichkowsky (2004) the investors can be segmented into risk-tolerant traders, confident traders, lossaverse young traders and conservative long term investors. For each segment their investment pattern and trading behavior are different.

Kaleem (2009) explores the relationship between portfolio decision making and the factors that may influence such decisions in Pakistan. The Study results conclude that the brokers/financial advisors considered as the foremost factor that influence stock selection by the investors.

The effective customer services can be used as a tool for retaining the customer base, say Edet et al. (2011). The study examines the situation prevalent in Nigeria and the paper identifies good customer service as imperative to client retention and organizational profitability. The study also reveals that there exists a significant positive correlation between the variables $(\mathrm{R}=0.807$, $\mathrm{n}=164, \mathrm{p}<0.01)$, implying that client retention is directly related to good customer service.

Paul and Garodia (2012) strongly points that there exist a gap between investor's expectation and their experience from broking firms. The study was based on $4 \mathrm{C}$ concept of the marketing mix. 4C'srepresent customer solution, customer cost, customer convenience and customer communication. 
And sample of 164 responses was examined to arrive at the above conclusion.

Meybodi (2012) written a research paper on measuring service quality using the SERVQUAL model: a case study of brokerage offices in Iran. The study results show that donor expectations and perceptions between investors' quality service brokerage offices in all areas, there are significant differences. Brokerage Managers, the models analyzed using the service quality, will be able to create gaps between the way the service provided, i.e., Investors and agents known to the agency planned to strengthen and reform pay problems.

Farzana et al. (2012) investigated two vital areas of behavioral finance; investors' awareness about capital market and the services rendered by the brokerage houses in Bangladesh. This study reveals that there is a significant gap between expected and actual service of brokerage houses. Reasons like high commission rate, non-cooperative attitude of brokers, high account maintenance fee etc. created such differences.

Individual Eccentric, Wealth Maximization, Risk Minimization, Brand Perception, Social responsibility, Financial Expectation, Accounting information, Government \& Media, Economic Expectation and Advocate recommendation factors are key in shaping individual investment decision say Sultana and Pardhasaradhi (2012).

Using micro data from the brokerage and automotive industries, Keloharju et al. (2012) find a strong positive relation between customer relationship, ownership of a company, and the size of the ownership stake. Investors are also more likely to purchase and less likely to sell shares of companies they frequent as customers. These effects are stronger for individuals with longer customer relationships.

Sankar and Maran (2013) look into customer's perception on market trading in India. The results show that Investors' main motive behind investment in share market is high returns. So the brokers should always suggest most profitable stocks to their customers.

Shukla and Upadhyaya (2013) examine the determinants of customer satisfaction for stock broking service. The study covers data from eighty respondents and twenty five variables were used. The study reveals that customer satisfaction in broking agencies is highly influenced by attributes of services and the way in which these services are delivered to the customer's. It was found in the study that customer's perceived significantly differently many of the services provided by the broking agencies.

Bashir et al. (2013) say that the investors are highly influenced by self-image/firm's image and accounting information like dividend paid, reputation of firm, feelings for a firm's products and services, get rich quick, firm's involvement in solving community problems, and firm's status in industry On other side factors that were found to be least influencing with respect to order of importance were friend or coworker recommendations, opinions of the firm's majority stockholder, recent price movement in the firm's stock, Religious Reason, Family member opinion and Broker recommendation. These were derived on the bases of a survey conducted among 125 individual investors in Pakistan.

Lalrindiki and Singh (2013) conducted a case study on customer relationship management with reference to Religare Securities. The study reveals that sixty 
percentages of the respondents think that customers' relationship policies are influential in further investing. And forty percentages are not very influenced with the customer relationship policies for further investment. If policies and services are good, then they will be satisfied with the company and invest further.

Maber et al. (2014) investigate the determinants and consequences of broker votes, one of the most pervasive but least understood reporting practices in the investment-research industry. Broker votes are ratings of the value of brokers' research services, and are produced by institutional investors (the "buy side") and solicited by broker dealers (the "sell side"). The results suggest that broker votes function as the nexus for a set of implicit contractual relationships between sell-side brokers, their affiliated analysts, and their buy-side clients.

In another research Jagongo and Mutswenje (2014) found out that the most important factors that influence individual investment decisions were: reputation of the firm, firm's status in the industry, expected corporate earnings, profit and condition of statement, past performance firm's stock, price per share, feeling about the economy and expected divided by investors.

A study conducted by Apparao and Babu (2015) among 576 respondents in Andhra Pradesh shows that an average 90 percent respondents are satisfied with the behavior and attitude of the members of the concerned stock broking firms. Moreover the majority of investors resort to the opinion of the member in a broking firm for selecting their investment pattern.

Barber and Odean (2001) in their article, check the possibility of implementing online advice engines than the traditional financial advisors. They are of the opinion that the investors who are comfortable with technology and have relatively uncomplicated finances will turn to on-line advice engines. The investors lacking the sufficient technical know-how can turn into traditional broking services.

A study conducted by Goswami (2003) examines the effectiveness of Indian online broking sites. The work revealed that the experienced online traders will take buying decision as their own and they will not rely on broker recommendations. Rahim (2013) says that the major benefits of online trading are wider choice and better value for investment. But the online investors are seriously struggling with the inadequacy of technology and poor communication network. A study by Vaddadi and Pratima (2016) suggests that stock broking firms need to enhance widespread use of online trading services. For this they need to organize relevant short term training programs and deploy user-friendly interface to encourage acceptance and quick adoption of online trading service among a diversified class of investors.

\section{RESEARCH GAP}

While examining the literature majority of the studies were much concerned on the topics such as what are the key factors which is shaping the investors behavior?, Whether the customers are satisfied with the service of their brokers?, How the stock broker can improvise their services? etc. Some studies came out with reasons for queries like why the investors are hesitated to trade with derivatives, what extend they are aware of such investment options and how the support by intermediaries helping them in shaping investment decisions. The outcomes of these 
works were peripheral by only providing answers to the above specific questions and the presented conclusions of these researches were not constructively examined by further studies. Most importantly these studies were unsuccessful to provide a specific client driven model for derivative trading. Especially in emerging economies like India the investors interest towards derivative instruments are increasing but the intermediaries are lacking with concrete measures for attracting and supporting the middle income/ low net worth group of investors. This research gap really motivated the researcher to develop a theoretical model for broking firms in order to address their clients belonging to diversified background.

\section{OBJECTIVES}

From the review of literature it is clear that the intermediaries can play a vital role in shaping investors behavior. Especially works of Ravichandran (2008), Kaleem (2009), Shafi (2014), Tripathy (2014), Apparao and Babu (2015), Vignesh and Lawrence (2016) stressed that the investors are verymuch relying on advice from financial experts or broking firms. In this context a survey among experts regarding the current level of service rendered by various stakeholders would helps to gather crucial inputs for further modeling. In view of the above the first objective was formulated. The works of Barber and Odean (2001), Hatzakis et al. (2010), Dhananjhay (2014), Vaddadi and Pratima (2016) emphasized the need for developing value added services for clients those who are trading with borking firms. Lalrindiki and Singh (2013) also explored the possibilities of developing customer oriented sevices. The above arguments further directed towards the thinking of how some unique trading strategies can be designed for borking firms based on their clients background. The second and third objectives were originated on the basis of the above notion. In this view the major objectives of the study are:

- To look into the expert opinion on current level of service provided by various stakeholders for trading with derivatives.

- To identify and evaluate trading strategies for clients with diversified background.

- To develop a theoretical model for ensuring more customized trading strategies based on client's background.

\section{RESEARCH METHODOLOGY AND HYPOTHESES}

An opinion poll has been organized among 200 executives those who are working with the stock trading arena in the Kerala region of the Republic of India. Here convenience sampling techniques were adopted. This survey extensively covers top level executives like Associate Vice Presidents, Regional \& Territory Managers of various broking firms, Middle level managers and Branch managers and lower level employees like marketing executives, back office assistants, stock dealers etc. The surveyed count includes 44 top level executives, 71 middle level managers and 85 lower level employees.

Though this survey was preliminarily conducted among experts, the outcome of this study was intended to develop a trading model for customers who wish to trade with financial derivatives. It is expected that results of this study serves both ends by supporting the clients to safely trade with 
derivatives and helps different broking units to enhance their revenue by attracting more client towards derivatives. The study was carried out with the following hypotheses:

H1: There is no significant variation in the evaluation of experts based on their position about support extended at by various stakeholders for Derivative ( $F \& O)$ trading.

H2: There is no significant association exist between the experts' position and their contract selection mechanism.

H3: There is no significant difference existed on the strategies suggested by experts to manage the customer's traffic.

A separate questionnaire was used for the data collection purpose and the same has been validated after conducting a pilot study among 20 executives.

Initially a total of 90 statements was used for the survey and the reliability of data so collected from pilot survey was analyzed by using the classical cornbach's alpha model. The groups of statements having a reliable value of 0.80 or more were retained for the final survey (Table 1). It can be stated that the sample size was proportional to the level of variation and the assumed level of error of the estimate of the population parameter of the study variable. After checking the reliability of the data 37 valid statements were retained for the final survey.

The sample size was arrived on the basis of the following notion. At $95 \%$ confidence level estimates of the means of these responses using the information on variances from the pilot study, the sample size was obtained based on each response. The sample size was determined by using the formula $n$ $\geq(1.96 \mathrm{sd} / \mathrm{se})^{2}$. When ' $\mathrm{n}$ ' is the sample size, 'sd' is the estimate of standard deviation, 'se' is the standard error of the estimate of the population parameter, and the value 1.96 is the critical value of normal test at 5 per cent level of significance. A calculated sample size of 188 was the maximum among all the sample size obtained based on the responses of different statements; finally 200 are fixed as the sample size.

The analytical tools used here will slightly differ from the framework developed by Jagongo and Mutswenje (2014). They used Principle Compound Analysis (PCA) to study the interrelation between variables. PCA seems to be viable to reduce many correlated variables to a more manageable number of uncorrelated variables. But MANOVA is useful to test for significant

Table 1. Cronbach's Alpha of variables used for survey

\begin{tabular}{cccc}
\hline Sl. No & Variable & No. Statements & $\begin{array}{c}\text { Cronbach's } \\
\text { Alpha }\end{array}$ \\
\hline 1. & Existing Scenario for derivative trading at exchange level & 3 & 0.87 \\
2. & Existing Scenario for derivative trading at firm level & 5 & 0.93 \\
3. & Existing Scenario for derivative trading at staff level & 4 & 0.88 \\
4. & Existing Scenario for derivative trading at partner level & 3 & 0.82 \\
6. & Preferred analytical measure for contract selection & 5 & 0.83 \\
9. & Strategies for attracting more funds towards F\&O segment & 7 & 0.80 \\
10. & Strategies to manage the customer base & 10 & 0.89 \\
\hline
\end{tabular}


differences between groups on two or more related dependent variables simultaneously while accounting for the correlation among the dependent variables. In this study MANOVA preferred as the groups are sampled from the same sampling distribution.

\section{DATA ANALYSIS AND RESULTS}

The data analysis part was segregated into three viz. Analyzing expert opinion of support extended by various stakeholders, analytical measures employed in contract selection and strategies for managing clients traffic. This part was done in order to get some meaningful input for developing a client driven trading model. The primary data so collected were analyzed by using MANOVA, Chi-square and paired sample't' test. Other descriptive statistical measures were also considered while analyzing the primary data.

\subsection{Current Level of support provided by various stakeholders in Derivative Trading}

The support provided by the Exchange, Broking firms, Partnering organizations and staffs for the smooth conduct of derivative trading was evaluated on the basis of opinion expressed by 200 working executives. The variables for evaluation were identified on the basis of the results of the pilot study and literature survey.

\subsubsection{Exchange Level}

Expert's opinion on three variables viz. Variety products offered in the derivative market, volume traded and revenue generated at exchange level was evaluated based on their position.

While considering the opinion of experts on the basis of their position the top level executives were in the opinion that there exists excellent support from the exchange level for derivative education and trading. The mean scores obtained on the opinion of top level executives were 4.750, 4.682 and 4.636 respectively (Table 2). Further, it is observed that the mean score of the responses of the experts does vary statistically significant at 5 per cent level of significance in the Multivariate tests ( $F$ value of Pillai's Trace 8757.60 with $p=.000<.05$ ). Here we may conclude that $\mathrm{H} 1$ has rejected.

\subsubsection{Firm Level}

A firm can promote derivative trading by way of organizing effective promotional programs at firm level, providing timely secretarial support to customers, providing education programs to investors, giving proper orientation for staff, ensuring excellent infrastructure, etc. This section is intended to analyze the experts' opinion on the aforesaid criteria at their respective firm.

From Table 3, it can be easily understood that the top level executives are on the opinion that their respective firms are offering adequate facilities for derivative trading (obtained mean scores were high in all these respects). The middle level executives were taking a neutral stand, but the lower level executives were not happy with the support extended at firm level. As the F value of Pillais trace is 6017.908 with $\mathrm{p}=0.000$ is less than 0.05 indicates that the mean score on response is statistically significant at $95 \%$ confidence level. In other words, we can say that the mean score responses of experts working at different 
position is statistically significant when we are considering these variables together. This finding further leading to the rejection of $\mathrm{H} 1$.

\subsubsection{Staff Level}

The supporting staffs working at different broking firms can play a vital role in derivative education and trading. Qualified and competent dealers are an essential prerequisite for derivative trading. It is generally presumed that staff with NCFM / $\mathrm{BCDE}$ qualifications in derivative module should deal F\&O transaction in trading terminals. At the same time top management should give adequate freedom to the supporting staffs for decision making. The current levels of support by staffs were evaluated on the basis of four variables.

It is found that the top level executives were not happy with the level of support extended by the staffs for derivative trading (as lowest mean scores obtained). The lower level executives expressed an opinion that the level of service rendered by staffs is admirable in south Kerala (with highest mean scores of 4.212, 4.176, 4.29 and 3.847 obtained respectively and presented in Table 4). From the analysis, it is clear that there exist a clear difference of opinion between the top level and lower level executives with respect to the quality of service rendered by the staffs. MANOVA test results show that the mean score of experts' opinion on derivative trading at staff level does vary statistically significant at the $5 \%$ level of significance as the F value of Pillai's trace 1925.723 with $\mathrm{p}$ value $0.000<0.05$ (H1 rejected).

\subsubsection{Partner Level}

Different stakeholders like SEBI, RBI, Commercial banks etc; can be considered as vital partners for facilitating education about derivatives and its application; and creating necessary provisions for financial assistance to retail investors. These partner level institutions play a key role in the Indian

Table 2. Derivative Trading at Exchange Level: Experts opinion

\begin{tabular}{|c|c|c|c|c|c|}
\hline \multirow{2}{*}{ Dependent variable } & \multirow{2}{*}{ Position of the respondent } & \multirow{2}{*}{ Mean } & \multirow{2}{*}{$\begin{array}{l}\text { Std. } \\
\text { Error }\end{array}$} & \multicolumn{2}{|c|}{ 95\% Confidence Interval } \\
\hline & & & & Lower Bound & Upper Bound \\
\hline \multirow{3}{*}{$\begin{array}{l}\text { Exchange Level- } \\
\text { Products Offered }\end{array}$} & Top level & 4.750 & .083 & 4.586 & 4.914 \\
\hline & Middle level & 3.197 & .065 & 3.068 & 3.326 \\
\hline & Lower Level & 2.141 & .060 & 2.023 & 2.259 \\
\hline \multirow{3}{*}{$\begin{array}{l}\text { Exchange Level- } \\
\text { Volume Traded }\end{array}$} & Top level & 4.682 & .096 & 4.493 & 4.871 \\
\hline & Middle level & 2.986 & .076 & 2.837 & 3.135 \\
\hline & Lower Level & 2.094 & .069 & 1.958 & 2.230 \\
\hline \multirow{3}{*}{$\begin{array}{l}\text { Exchange Level- } \\
\text { Revenue Generated }\end{array}$} & Top level & 4.636 & .080 & 4.479 & 4.793 \\
\hline & Middle level & 3.183 & .063 & 3.059 & 3.307 \\
\hline & Lower Level & 1.788 & .057 & 1.675 & 1.901 \\
\hline
\end{tabular}

Source: Surveyed Data 
Table 3. Derivative Trading at Firm Level: Experts opinion

\begin{tabular}{|c|c|c|c|c|c|}
\hline \multirow{2}{*}{ Dependent variable } & \multirow{2}{*}{ Position of the respondent } & \multirow{2}{*}{ Mean } & \multirow{2}{*}{$\begin{array}{l}\text { Std. } \\
\text { Error }\end{array}$} & \multicolumn{2}{|c|}{ 95\% Confidence Interval } \\
\hline & & & & Lower Bound & Upper Bound \\
\hline \multirow{3}{*}{$\begin{array}{l}\text { Firm Level- } \\
\text { Promotional Strategies }\end{array}$} & Top level & 4.364 & .095 & 4.176 & 4.551 \\
\hline & Middle level & 3.169 & .075 & 3.022 & 3.316 \\
\hline & Lower Level & 2.376 & .068 & 2.242 & 2.511 \\
\hline \multirow{3}{*}{$\begin{array}{l}\text { Firm Level- Secretarial } \\
\text { support extended }\end{array}$} & Top level & 4.477 & .105 & 4.271 & 4.683 \\
\hline & Middle level & 2.972 & .082 & 2.810 & 3.134 \\
\hline & Lower Level & 1.953 & .075 & 1.805 & 2.101 \\
\hline \multirow{3}{*}{$\begin{array}{l}\text { Firm Level- Education } \\
\text { program for investors }\end{array}$} & Top level & 4.455 & .096 & 4.264 & 4.645 \\
\hline & Middle level & 2.845 & .076 & 2.695 & 2.995 \\
\hline & Lower Level & 1.824 & .069 & 1.687 & 1.960 \\
\hline \multirow{3}{*}{$\begin{array}{l}\text { Firm Level- } \\
\text { Orientation program } \\
\text { for staffs }\end{array}$} & Top level & 4.432 & .094 & 4.246 & 4.618 \\
\hline & Middle level & 3.014 & .074 & 2.868 & 3.161 \\
\hline & Lower Level & 1.647 & .068 & 1.513 & 1.781 \\
\hline \multirow{3}{*}{$\begin{array}{c}\text { Firm Level- } \\
\text { Infrastructural facilities }\end{array}$} & Top level & 4.386 & .092 & 4.204 & 4.568 \\
\hline & Middle level & 3.056 & .073 & 2.913 & 3.200 \\
\hline & Lower Level & 1.871 & .066 & 1.740 & 2.001 \\
\hline
\end{tabular}

Source: Surveyed Data

financial market. SEBI and other regulators can initiate different programs at the investors' level to educate about derivatives. The banks and financial institutions can support investors by ensuring funds by way of loans. This section is intended to analyze the expert's opinion on the support services extended from partner level institutions for derivative segment.

Top level executives are on the opinion that support extended by partner level institutions for derivative trading are exceptional while comparing with the opinion executives working in other positions. This conclusion is arrived on the basis that preference will be arranged on the basis of the respective mean score obtained. The executives working at lower levels are of the opinion that the partner level support is inadequate. While considering the opinion of experts working in different position together; it is found that the mean score obtained do signifies statistically at 5\% level of significance. Where the $\mathrm{F}$ value of Pillais Trace 2992.712 with $\mathrm{p}=0.000<0.05$ at $95 \%$ confidence level (H1 rejected). The results are presented in Table 5.

\subsection{Experts Preferred Analytical Measure for contract Selection}

Five different variables considered to find 
the experts preferred mechanism for selecting and $\mathrm{F} \& \mathrm{O}$ contract. The variables considered are economy- IndustryCompanywide factors, Historical price movements, general market information, wild guesses and other methods. The opinion of all categories of experts is listed in the below mentioned table.

Around $32.5 \%$ of the executives choose historical price movements as an important criterion for $\mathrm{F} \& \mathrm{O}$ contract selection out of this $36.4 \%$ are top level executives. Only $0.5 \%$ of the executives select contract on the basis of wild guesses. General market information considered to be the second best criteria for all categories of respondents with a count of $32 \%$. 19.5\% favored that Economy-Industry- Company analysis can be used as the best mechanism for contract selection. Further, the result of chi-square test of independence shows that the value of chi-square is not significant at 5 per cent level of significance. Here the probability value 0.789 is greater than 05 . Therefore, it is concluded that there is no association between the position of the experts and their contract selection method (H2 accepted). The results are presented in the Table 6 .

\subsection{Strategies for managing the client's traffic}

In order to identify the most suitable strategies for managing client's traffic five different variables identified. These variables are customer education before derivative trading, providing timely expertise, advise, frequent monitoring the contract position, counseling in case of failure and arranging financial assistance from internal and

Table 4. Derivative Trading at Staff Level: Experts opinion

\begin{tabular}{|c|c|c|c|c|c|}
\hline \multirow{2}{*}{ Dependent variable } & \multirow{2}{*}{ Position of the respondent } & \multirow{2}{*}{ Mean } & \multirow{2}{*}{$\begin{array}{l}\text { Std. } \\
\text { Error }\end{array}$} & \multicolumn{2}{|c|}{ 95\% Confidence Interval } \\
\hline & & & & Lower Bound & Upper Bound \\
\hline \multirow{3}{*}{$\begin{array}{l}\text { Staff Level- } \\
\text { Qualification of staffs }\end{array}$} & Top level & 2.114 & .107 & 1.902 & 2.325 \\
\hline & Middle level & 3.113 & .084 & 2.946 & 3.279 \\
\hline & Lower Level & 4.212 & .077 & 4.060 & 4.364 \\
\hline \multirow{3}{*}{$\begin{array}{l}\text { Staff Level- Quality of } \\
\text { service given }\end{array}$} & Top level & 1.500 & .118 & 1.268 & 1.732 \\
\hline & Middle level & 3.113 & .093 & 2.930 & 3.296 \\
\hline & Lower Level & 4.176 & .085 & 4.009 & 4.344 \\
\hline \multirow{3}{*}{$\begin{array}{l}\text { Staff Level- Skill and } \\
\text { Competency }\end{array}$} & Top level & 1.750 & .109 & 1.535 & 1.965 \\
\hline & Middle level & 3.085 & .086 & 2.915 & 3.254 \\
\hline & Lower Level & 4.294 & .079 & 4.139 & 4.449 \\
\hline \multirow{3}{*}{$\begin{array}{l}\text { Staff Level- Freedom } \\
\text { for decision making }\end{array}$} & Top level & 2.273 & .125 & 2.027 & 2.518 \\
\hline & Middle level & 3.042 & .098 & 2.849 & 3.236 \\
\hline & Lower Level & 3.847 & .090 & 3.670 & 4.024 \\
\hline
\end{tabular}

Source: Surveyed Data 
Table 5. Derivative Trading at Partner Level: Experts opinion

\begin{tabular}{|c|c|c|c|c|c|}
\hline \multirow{2}{*}{ Dependent variable } & \multirow{2}{*}{ Position of the respondent } & \multirow{2}{*}{ Mean } & \multirow{2}{*}{$\begin{array}{c}\text { Std. } \\
\text { Error }\end{array}$} & \multicolumn{2}{|c|}{ 95\% Confidence Interval } \\
\hline & & & & Lower Bound & Upper Bound \\
\hline \multirow{3}{*}{$\begin{array}{l}\text { Partner Level-SEBI/ } \\
\text { Exchange initiated } \\
\text { programs }\end{array}$} & Top level & 4.136 & .088 & 3.962 & 4.311 \\
\hline & Middle level & 2.986 & .070 & 2.849 & 3.123 \\
\hline & Lower Level & 1.835 & .064 & 1.710 & 1.961 \\
\hline \multirow{3}{*}{$\begin{array}{l}\text { Partner Level- Tie up } \\
\text { with Financial } \\
\text { institutions for } \\
\text { arranging funds for } \\
\text { investors }\end{array}$} & Top level & 2.909 & .092 & 2.728 & 3.090 \\
\hline & Middle level & 2.634 & .072 & 2.491 & 2.777 \\
\hline & Lower Level & 1.471 & .066 & 1.340 & 1.601 \\
\hline \multirow{3}{*}{$\begin{array}{c}\text { Partner Level- } \\
\text { Counseling to investors } \\
\text { by experts from govt. } \\
\text { agencies }\end{array}$} & Top level & 4.295 & .084 & 4.130 & 4.461 \\
\hline & Middle level & 2.986 & .066 & 2.856 & 3.116 \\
\hline & Lower Level & 1.435 & .060 & 1.316 & 1.554 \\
\hline
\end{tabular}

Source: Surveyed Data

external sources. It is perceived that through these strategies the advisors (firm) would be able to provide more customized service to their clients. Apart from this the customers were classified into experienced and inexperienced customers in the context of derivative trading. Experienced customers here refer those who have sufficient experience in trading with derivative instruments and inexperienced customers are those who have less than one year of trading experience with derivatives.

The experts are at the judgment that the total customers have to be separated on the basis of their experience. The inexperienced investors can be retained through implementing strategies like providing proper orientation before $\mathrm{F} \& \mathrm{O}$ trading, frequent monitoring of contract positions and giving timely expert advice (highest mean values of $1.845,1.130$ and 1.115 obtained respectively). The results of these measurements are given in Table 7 and Table 8. In the case of experienced investors the executives suggested the following strategies

viz. arranging counseling for the investors who has suffered marginally huge losses and arranging financial assistance from internal/ external sources for $\mathrm{F} \& \mathrm{O}$ trading. The above strategies are designed on the bases of mean score obtained from the response of experts working in stock trading field. Paired sample T-test is a powerful tool to examine the statistical significance of the above mean scores. In view of the above, the following hypothesis were generated.

Further the significance of the above scenario can be evaluated by using paired sample $t$ test.

Further, it can be inferred that the mean scores of opinion obtained from experts with respect to Pair 1 (Educating them properly before entering into a contract), Pair 2 (Providing timely expertise, advice) and pair 5 (Arranging financial assistance from internal/ external sources) are statistically significant at $95 \%$ confidence level as $\mathrm{p}$ value $<0.05$. In the case of the above three pairs we need to reject H3. While considering opinion expressed by experts on 
Pair 3(Monitoring contract position) and Pair 4 (Counsel them in case of failures); it can be inferred that the mean scores obtained are not statistically significant at 5\% level of significance (where $p$ values are much higher than 0.05 ), hence we can accept H3 with respect to the above two questions. From the above, it can be easily inferred that frequent monitoring of contract position and specialized counseling are equally important for all kinds of investors irrespective of their experience in $\mathrm{F} \& \mathrm{O}$ trading.

\section{DISCUSSION OF RESULTS}

The experts arguments regarding the present level of support rendered by various stakeholders for derivative trading was examined in the initial phase on the context of stock exchanges, broking firms, supporting staffs and partnering institutions. These opinions were subsequently tested with multivariate statistical tools. The top level executives expressed greater satisfaction towards the trading facilities extended to customers by stock exchanges, broking firms, and partnering institutions, but they are on the opinion that we need to sensitize the supporting staff regarding their approach with the clients and trading mechanism. The top executives strongly believes that the staff working in broking firms need to render much better service to the clients who wish to trade with derivatives. Again out of which the top executives are not at all happy with the quality of service rendered by staffs (mean score 1.5), their skill and competency (mean score 1.75) and qualification (mean score 2.1 ). This points that we need to really work at the supporting staff level to bring some positive impact. Moreover the supporting staff are the first contact point to the prospective clients. Interestingly the supporting staff were not quite aware about the facilities/ support offered at exchange level, firm level and partnering institutions level. These chaos can be rectified through proper orientation programs. It is also advised that the broking units should ensure that their staffs are possessing NCFM or

Table 6. Mechanism for contract selection

\begin{tabular}{|c|c|c|c|c|c|c|c|c|}
\hline \multicolumn{3}{|c|}{ Contract Selection Mechanism } & \multirow{2}{*}{$\begin{array}{c}\begin{array}{c}\text { Economy- } \\
\text { Industry- } \\
\text { Company- } \\
\text { factors }\end{array} \\
11\end{array}$} & \multirow{2}{*}{$\begin{array}{c}\begin{array}{c}\text { Historical } \\
\text { price } \\
\text { movements }\end{array} \\
16\end{array}$} & \multirow{2}{*}{$\begin{array}{c}\begin{array}{c}\text { General } \\
\text { market } \\
\text { information }\end{array} \\
11\end{array}$} & \multirow{2}{*}{$\begin{array}{c}\text { Wild } \\
\text { guess } \\
\\
0\end{array}$} & \multirow{2}{*}{$\begin{array}{c}\text { Others } \\
6\end{array}$} & \multirow{2}{*}{$\begin{array}{c}\text { Total } \\
44\end{array}$} \\
\hline \multirow{6}{*}{ Position } & \multirow{2}{*}{ Top level } & Count & & & & & & \\
\hline & & $\%$ & $25.0 \%$ & $36.4 \%$ & $25.0 \%$ & $.0 \%$ & $13.6 \%$ & $100.0 \%$ \\
\hline & \multirow{2}{*}{$\begin{array}{c}\text { Middle } \\
\text { level }\end{array}$} & Count & 12 & 20 & 27 & 0 & 12 & 71 \\
\hline & & $\%$ & $16.9 \%$ & $28.2 \%$ & $38.0 \%$ & $.0 \%$ & $16.9 \%$ & $100.0 \%$ \\
\hline & \multirow{2}{*}{$\begin{array}{l}\text { Lower } \\
\text { Level }\end{array}$} & Count & 16 & 29 & 26 & 1 & 13 & 85 \\
\hline & & $\%$ & $18.8 \%$ & $34.1 \%$ & $30.6 \%$ & $1.2 \%$ & $15.3 \%$ & $100.0 \%$ \\
\hline \multirow{2}{*}{\multicolumn{2}{|c|}{ Total }} & Count & 39 & 65 & 64 & 1 & 31 & 200 \\
\hline & & $\%$ & $19.5 \%$ & $32.5 \%$ & $32.0 \%$ & $.5 \%$ & $15.5 \%$ & $100.0 \%$ \\
\hline
\end{tabular}

Source: Surveyed Data 
Table 7. Strategies for managing the client's traffic

\begin{tabular}{|c|c|c|c|c|c|}
\hline & Strategies & Mean & $\mathbf{N}$ & $\begin{array}{c}\text { Std. } \\
\text { Deviation }\end{array}$ & $\begin{array}{l}\text { Std. } \\
\text { Error } \\
\text { Mean }\end{array}$ \\
\hline \multirow{2}{*}{ Pair 1} & $\begin{array}{l}\text { Educating them properly before entering in to } \\
\text { contract (Experienced) }\end{array}$ & 1.0200 & 200 & .17248 & .01220 \\
\hline & $\begin{array}{l}\text { Educating them properly before entering in to } \\
\text { contract (Inexperienced) }\end{array}$ & 1.8450 & 200 & .36281 & .02565 \\
\hline \multirow{2}{*}{ Pair 2} & Providing timely expertise advice (Experienced) & 1.0250 & 200 & .15652 & .01107 \\
\hline & Providing timely expertise advice (Inexperienced) & 1.1150 & 200 & .31982 & .02261 \\
\hline \multirow{2}{*}{ Pair 3} & $\begin{array}{l}\text { Monitoring contract position frequently } \\
\text { (Experienced) }\end{array}$ & 1.1100 & 200 & .31367 & .02218 \\
\hline & $\begin{array}{l}\text { Monitoring contract position frequently } \\
\text { (Inexperienced) }\end{array}$ & 1.1300 & 200 & .33715 & .02384 \\
\hline \multirow{2}{*}{ Pair 4} & Counsel them in case of failures (Experienced) & 1.1750 & 200 & .38092 & .02694 \\
\hline & Counsel them in case of failures (Inexperienced) & 1.1200 & 200 & .32578 & .02304 \\
\hline \multirow{2}{*}{ Pair 5} & $\begin{array}{l}\text { Arranging financial assistance from internal/ } \\
\text { external sources (Experienced) }\end{array}$ & 1.8050 & 200 & .39719 & .02809 \\
\hline & $\begin{array}{l}\text { Arranging financial assistance from internal/ } \\
\text { external sources (Inexperienced) }\end{array}$ & 1.1500 & 200 & .35797 & .02531 \\
\hline
\end{tabular}

Source: Surveyed Data

BCDE derivative module qualifications before posting them into trading terminals.

In the second phase it was examined to check what extend the experts are rational in selecting a contract for their customers. Usually the experts mechanism may differ in selecting a derivative contract. Majority $(32.5 \%)$ wish to consider historical price movements as the key factor for selecting a derivative contract, and irrespective of the position they are on the opinion that the wild guesses will not serve any positive impact on derivative trading process. Chi-square test further proves that experts are preferring a uniform contract selection mechanism ( $p$. value 0.789 is greater than 05 ).

A separate questionnaire was used in the third phase by providing various strategies to experts for managing their clients traffic. The experts unanimously agreed that a separation is required among their clients based on the trading experience. The paired sample t test results argues that monitoring contract position and specialized counseling is important for all customers irrespective of their experience. For experienced investors it is suggested to organize some promotional mechanism that would motivate them to trade with derivatives. Here the staffs can offer some liberalized maintenance margin for derivative trading or they can assist their client for obtaining finance from some lending institutions etc. As far as inexperienced investors are concerned the experts are on the opinion that such client should strictly go through an orientation program on derivative trading. In the light of the above inputs from the data analysis a 
Table 8. 't' test result of Strategies for managing the client's traffic

\section{Paired Differences}

95\% Confidence Interval of the Difference

\begin{tabular}{|c|c|c|c|c|c|c|c|c|c|}
\hline & & Mean & $\begin{array}{c}\text { Std. } \\
\text { Deviation }\end{array}$ & $\begin{array}{l}\text { Std. Error } \\
\text { Mean }\end{array}$ & Lower & Upper & $\mathbf{t}$ & df & $\begin{array}{c}\text { Sig. (2- } \\
\text { tailed) }\end{array}$ \\
\hline Pair 1 & $\begin{array}{l}\text { Educating them } \\
\text { properly before } \\
\text { entering in to } \\
\text { contract }\end{array}$ & -.8250 & .39389 & .02785 & -.8799 & -.7700 & -29.62 & 199 & $.000 *$ \\
\hline Pair 2 & $\begin{array}{l}\text { Providing timely } \\
\text { expertise advice }\end{array}$ & -.0900 & .36409 & .02575 & -.1407 & -.0392 & -3.496 & 199 & $.001 *$ \\
\hline Pair 3 & $\begin{array}{c}\text { Monitoring } \\
\text { contract position }\end{array}$ & -.0200 & .48037 & .03397 & -.0869 & .04698 & -.589 & 199 & $.557 *$ \\
\hline Pair 4 & $\begin{array}{l}\text { Counsel them in } \\
\text { case of failures }\end{array}$ & .05500 & .52282 & .03697 & -.0179 & .12790 & 1.488 & 199 & $.138 *$ \\
\hline Pair 5 & $\begin{array}{c}\text { Arranging } \\
\text { financial } \\
\text { assistance from } \\
\text { internal/ external } \\
\text { sources }\end{array}$ & .65500 & .49720 & .03516 & .58567 & .72433 & 18.630 & 199 & $.000 *$ \\
\hline
\end{tabular}

Source: Surveyed Data

possible working model was developed for derivative trading in the subsequent session.

\section{CLIENT DRIVEN MODEL FOR TRADING WITH FINANCIAL DERIVATIVES}

Considering the above opinion a theoretical model was developed to facilitate derivative trading. This model is intended to create a pathway to the service providers for offering more customized service to the ordinary investors. The model developed after considering the opinion from working executives who have close association with the capital market. The model is presented in Figure 1.

\subsection{Technical Factors}

The F\&O contract selection is subject to several technical factors like the economic situation, industrial performance, historical price movements and the information available from the capital market. In fundamental analysis it is believed that Economy- Industry- Company (Fundamental analysis) frameworks play a vital role in influencing investment decision. While selecting a contract; the investors would like to select an extremely safe and promising investment option from a performing industry belonging to a stable economy. From another dimension the technical analysts tend to believe that the past trend is likely to influence in the future also. They usually will consider the stock price movement (or index movement) for a sizeable period. In the words of Harrington (2003) 'Fundamental analysis chooses stocks to buy; technical analysis chooses when to buy'. Above all in stock market it is 


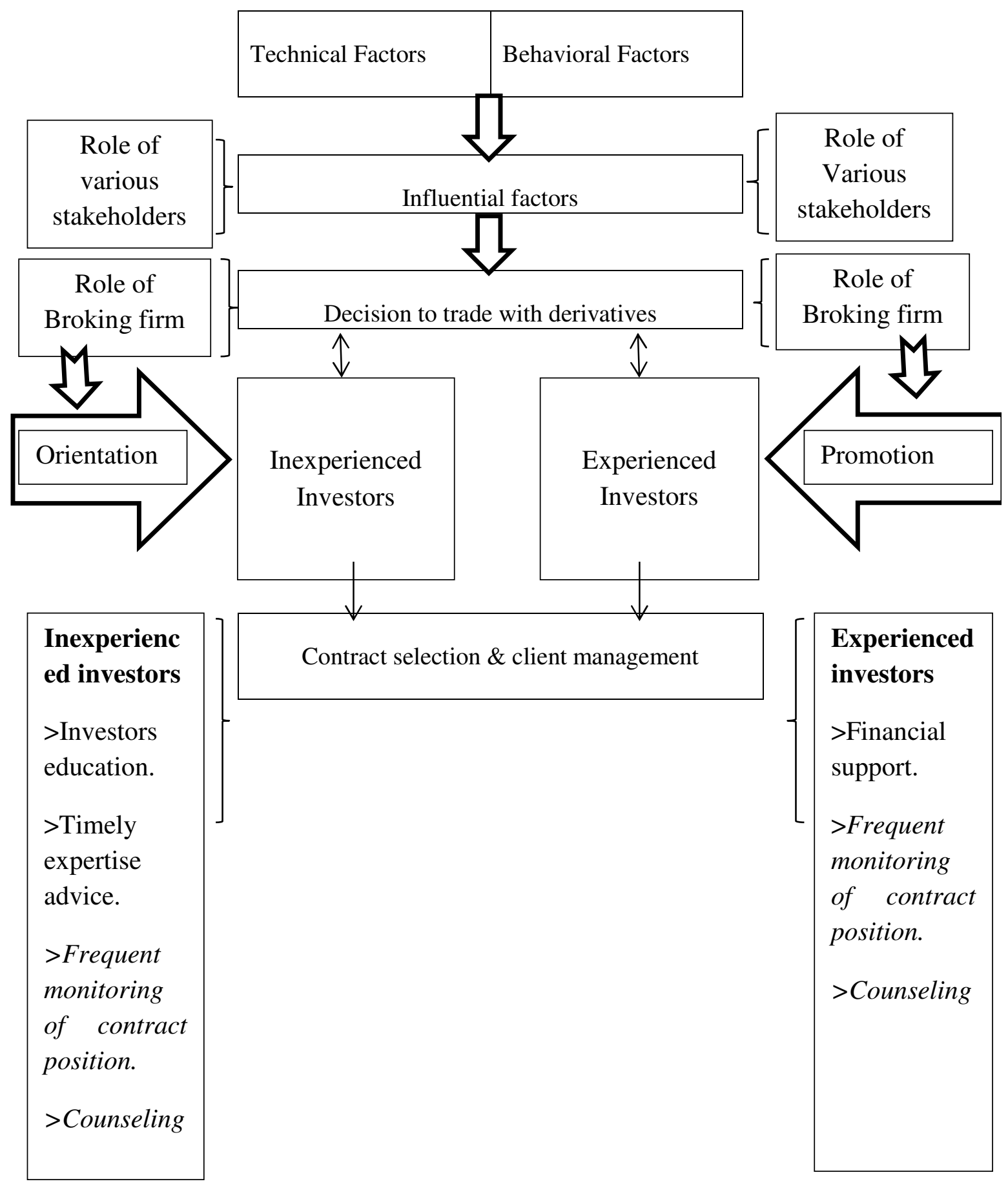

Figure 1. Client Driven Model for Trading with Derivatives 
generally believed that the security's price will reflect all available information from economy, industry, company etc. (Random Walk Theory). Fama (1995) says 'whenever a new piece of information arrives, the investors will behave accordingly; i.e. If the information is favorable they will invest and if the information is unfavorable they will divest'.

\subsection{Behavioral Factors}

Various factors like confidence, knowledge, desire to get knowledge, previous trading experience, social influence, influence by brokers etc. can play a major role in shaping the behavior of retail investors. Such factors can become a major block or motive for their decision to trade with derivatives. These factors are identified by observing the study result of Hon (2012). Using factor analysis, he identified five factors that capture the behaviour of small investors in derivatives markets in Hong Kong. The factors are personal background, reference group, return performance, risk tolerance, and cognitive style.

\subsection{Role of influential factors}

Even though the investment decisions are driven by the motives of maximization of return and minimization of risk; there are several other factors can also influence them towards derivative contracts. Jagongo and Mutswenje (2014) say that the investors can be influenced by accounting information, self image of firms, broker's recommendation and their personal financial needs. But in this study a different perspective was used for examining the influencing factors.

Here the different stakeholders can play a vital role in attracting more investors toward F\&O segment. The stock exchanges can attract more investors towards derivative segment by designing and offering innovative tools for managing their risk in investment. The broking firms can offer excellent infrastructure, rendering support to investors by trained staff, providing education programs to the investors etc. for facilitating smooth trading. The regulators like SEBI can play a vital role via creating and enforcing rules for protecting the interest of retail investors. Other partner level institutions like financial institutions and other government agencies can support F\&O trading by way of arranging funding for trading purpose (loan for premium, margin money, etc.), counsel the investors about the pros and cons in derivative investment, etc. The stock analysts, rating agencies, etc. can support the retail investors through rendering timely advisory services. All the above stakeholders can together influence the retail investors by creating a conductive and secured trading environment.

\subsection{Categorization of investors}

The investors can be classified as experienced and inexperienced investors. The investors do not have sufficient knowledge and experience in derivative trading can be categorized as inexperienced investors and the investors those who are presently trading with derivatives can be categorized as experienced investors.

The inexperienced investors can be attracted towards this segment through orientation programs and the experienced investors can be retained through promotional strategies. An orientation should be given to inexperienced investors via offering mock trading terminals at firm level, 
specialized coaching programs, education/ awareness classes etc. This suggestion is strongly agreeing with the view of Stulz (2004) as he argues that 'those in charge of taking derivatives positions must have the proper training'. The experienced investors should be motivated to trade more by way of offering attractive brokerage, liberalized maintenance margin, arranging funding for investment through a broker initiated tie-ups with banks and financial institutions etc.

\subsection{Contract selection and Client management}

Once the investors come across derivative investment; the broking firms should develop alternative strategies to manage their customer base. For inexperienced investors providing an in-depth education about financial derivatives and its functioning is seems to be highly useful. They should be also supported by way of giving timely expertise advice.

Monitoring the investment portfolio by a third party (preferably by the broker) is highly beneficial for experienced as well as inexperienced investors to safeguard their investment. For facilitating this firm can also go for the support of Intelligent Decision Support Systems by using multiple electronic- web based gadgets. Narawade et al. (2012) proposed a computer based system to analyze the stock market database of clients and give the recommendation with help of trading experts. Such kind of proposals can be considered for monitoring and communicating the financial position of clients.

The firm should support the investors by providing the proper information regarding their contract position and giving timely advice regarding selection, cancellation and modification of $\mathrm{F} \& \mathrm{O}$ contracts. Proper psychological counseling from external experts can be organized for the investors those who have suffered financial losses. Even though such practices are not followed by broking firms in the present scenario; from the societal angle it should become the responsibility of firms to serve their customers financially and mentally. Broking firms can go for a tie-up with banks and financial institutions in order to arrange sufficient fund for their customers to support their trading activities. This financial support can be extended by way of organizing fund from financial institutions for the initial premium (option contract), margin money (futures), recovering / repaying contract obligation, etc. At the same time internal financial assistance can be offered by way of charging lesser brokerage / commission etc.

\section{RECOMMENDATIONS AND CONCLUSION}

The outcome of this study can be segregated in to three segments. Initially this work examines current level of support extended by various stakeholders in derivative trading. This objective was satisfied by evaluating the opinion of experts regarding support given by various stakeholders' viz. exchange, broking firms, staffs, regulators etc. The top level executives working in broking firms are satisfied with support service provided for derivative trading by various stakeholders like stock exchange, broking firms, partner level institutions, customers, etc. But the top level executives are not so happy with the service extended at staff level; and this clearly indicates that the necessary orientation should be given to staffs working in broking firms regarding derivative trading. The multivariate analysis results also signifies 
that some drastic change is required for staffs working with broking firms as they are the primary access point for the customers in derivative trading.

The second purpose was to develop some viable trading strategies for customers with diversified background. The experts are on the opinion that segregation of clients based on their experience is seems to be a viable model for ensuring more customized service. The possibility of such segmentation was further examined statistically and it is identified that proper orientation should be given to the inexperienced customers and the experienced one can be attracted trough proper promotional strategies. In this view it is suggested to establish mock trading terminals in broking units for providing sufficient practical knowledge to inexperienced investors. Several investors would like to get adequate practical knowledge about the functioning of derivatives. But inadequate infrastructures usually force them to undertake some real contracts even before getting sufficient exposure with different derivative instruments. Establishing mock trading terminals would help to overcome the aforesaid problem to a certain extent. Moreover derivatives in the Indian context are used as a hedging tool rather than a speculative tool. At this context the broking firms should ensure adequate back up from the investors in the form of portfolio, margin money, etc.; before allowing them for undertaking a derivative contract. This would enable the investors to repay their obligations from derivative contracts internally rather that looking for funding from external sources.

The third objective of this study was fulfilled by way of developing a client driven trading model. The viability of this model has to be examined further by testing the same in a practical platform. This model suggest that for promoting trading in derivatives; adequate strategies have to be developed at the firm level. Before designing a strategic investor should be classified on the basis of their experience in derivative trading. The inexperienced investors should be strictly channeled towards orientation programs and the existing investors can be attracted through promotional programs. Here the broking firms can provide orientation to the inexperienced investors by conducting awareness classes, distributing educational materials, facilitating mock trading terminals, organizing opportunity to interact with successful players, etc. For attracting experienced clients the firms need to use more promotional strategies like offering liberalized margin, financial support, or arranging financial support from external agentcies, dicounted broking rates etc.

The major shortfall of the suggested model is as it can be used only for channelizing the clients based on their experience and preferences. This model donot serve a client or a broking unit in the following contexts like; deciding the quantum of investment, fixation of margin money, choosing the time horizon for investment etc. The clients were simply classified on the basis of their experience in derivative trading, other possible demographic factors like income, savings, occupation etc. totally ignored in this model. This model is a staff driven model and not of a self dependant structure. For successful implementation of this concept we need enormous support from the staff and management of broking units. Implication of this model is only confined with retail investors and do not useful for institutional investors and high networth investing groups. The above limitations pointing towards the scope of some future research on topics like:

- A strategic business model for 


\title{
СТРАТЕГИЈЕ ТРГОВИНЕ ЗАСНОВАНЕ НА КЛИЈЕНТИМА: ПРАКТИЧНО МОДЕЛОВАЊЕ У КОНТЕКСТУ ТРЖИШТА ФИНАНСИЈСКИХ ДЕРИВАТИВА
}

\author{
Aravind Mohanan Potti
}

\section{Извод}

Финансијски деривативи су у великој мери препоручени од стране финансијских саветника и брокера како би се заштитила инвестициона позиција њихових клијената. Међутим, због хетерогености између група малопродајних инвеститора, оне нису у позицији да понуде више прилагођене услуге својим клијентима. Ова студија је израђена на основу истраживања спроведеног међу 200 стручњака који раде у различитим брокерским фирмама. Мишљења која су прикупљена од експерата оцењивана су различитим статистичким методама како би се одабрале одговарајуће стратегије. Статистички алати као што су "MANOVA", "Chi-square, paired sample" - 't' тест, итд., коришћени су за анализу одрживости експертских препорука. На основу ове емпиријске анализе идентификоване су неке стратегије за трговање дериватима и формулисан је теоријски модел за рад са диверзификованом групом малопродајних инвеститора.

Кључне речи: улога стејкхолдера, управљање саобраћајем клијента, пословни модел вођен клијентима

derivative trading based on customers income.

- Chanalising risk from individuals to broking institutions, new $\mathrm{C} 2 \mathrm{~B}$ strategies.

- Strategic trading models for institutions to hedge their investments.

\section{References}

Allen, F., \& Santamero, A.M. (1998). The theory of Financial Intermediation. Journal of Banking and Finance, 21 (1), 1461-1485.

Apparao, E., \& Babu, N.K. ( 2015). A survey on Investors Perception towards Investment Avenues in Godavari Districts of Andhra Pradesh. Acme Intellects International Journal of Research in Management, Social Sciences \& Technology. 9 (9), 1-13.

Barber, M.B., \& Odean, T. (2001). The internet and investor. Journal of Economic
Perspectives, 15 (1), 41-54.

Bashir, T., Javed, A., Ali Butt, A., Azam, N., Tanveer, A., \& Ansar, I. (2013). An Assessment Study on the "Factors Influencing the Individual Investor Decision Making Behavior". IOSR Journal of Business and Management, 9(5), 37-44.

Dhananjhay, G. (2014). Recent Trend of Stock Broking Industry in India: A Perspective. SRM Management Digest, 3 (1), 1-9.

Edet, N.B, Etim, U.O., \& Etesin, U.U. (2011). Effective customer service: A tool for client retention among stock broking firms in Nigeria. African Journal of Business Management, 5 (20), 7987-7991.

Fama, E.F. (1995). Random Walk in Stock Market Prices. Financial Analyst Journal. 51(1), 75-80.

Farzana, W., Rahman, M.I., \& Mazumder, M.N.H. (2012). Behavioral Financing: 
Demographic Factors and Services of and Investment Decisions. The Review of Brokerage Houses in Bangladesh. World Financial Studies, 25 (10), 2921-2958.

Journal of Social Sciences, 2 (4), 15-33.

Goswami, C. (2003). How Does Internet Sock Trading in India Work ?. Vikalpa, 28 (1), 91-98.

Harrington, C. (2003). Fundamental vs. Technical Analysis: Controversy between the two schools is still alive and well. CFA Magazine. JAN-Feb 2003, 36-37.

Hatzakis, E.D., Nair, S.K., \& Pinedo, M.L. (2010). Operations in Financial Services - An Overview. Production and Operations Management, 19 (6), 633-664.

Hon, T.Y. (2012). The Behaviour of Small Investors in the Hong Kong Derivatives Markets: A factor analysis. Journal of Risk and Financial Management, 5, 59-77.

Jagongo, A., \& Mutswenje, V.S. (2014). A Survey of the Factors Influencing Investment Decisions: The Case of Individual Investors at the Nairobi Stock Exchange. International Journal of Humanities and Social Science, 4 (4), 92-102.

Kaleem, A., Wajid, A.J., \& Hussain, S.H. (2009). Factors affecting financial advisor's perception in Portfolio Management: with reference to Pakistan. Oxford Business \& Economics Conference Program, St. Hugh's College, Oxford University, Oxford, UK, June 24-26, 2009.

Kavitha, C. (2015). Investor's attitudes towards Stock Market investment. International Journal of Scientific Research and Management, 3 (7), 3356-3362.

Kaur, N., \& Singh, G. (2015). Role of Brokers/Institutional Investors to Induce Investment in Indian Stock Markets. International Journal of Advanced Research, 3 (7), 1545-1562.

Keloharju, M., Knupfer, S., \& Linnainmaa, J. (2012). Do Investors Buy What They Know? Product Market Choices
Lalrindiki, J., \& Singh, A.K. (2013). Customer Relationship Management: A Case Study of Religare Securities Maraimalai Nagar. International Journal of Management and Social Sciences Research, 2 (8), 65-70.

Maber, A.D., Groysberg, B., \& Healy, P.M. (2014). The Use of Broker Votes to Reward Brokerage Firms' and Their Analysts' Research Activities. Harvard Business School- Working Paper, 14-074.

Meybodi, A.R. (2012). Measuring service quality using SERVQUAL model: a case study of brokerage offices in Iran. International Journal for Quality research, 6 (1), 55-61.

Mohanthy, N. (2011). Cost of Trading in Stock Exchanges: a Perspective. NSE Working Paper, WP/2/2011, 02-14.

Narawade, V.E., Parab, A.M., \& Shirsekar, C.S. ( 2012). Intelligent Decision Support System for Recommendations and Analysis of Indian Stock Exchanges. International Journal of Engineering Research and Applications, 2 (3), 16031608.

Paul, T., \& Garodia, A. (2012). Equity Investors Expectations and Experience - Gap Analysis. Asia Pacific Journal of Marketing \& Management Review, 1 (3), 46-55.

Rahim, A. (2013). Problems and Prospects of Online Share Trading practices in India. International Journal of Marketing, Financial Services \& Management Research, 2 (4), 150-155.

Rajkumar, P., \& Kavitha, L.N. (2015). Relevance of Stock Broking Industry in Capital Market with Special Reference to BSE, Mumbai. International Journal of Latest Technology in Engineering, Management \& Applied Science, 6 (10), 4247. 
Ravichandran, K. (2008). A study on Journal of Innovative Research in Investors Preferences towards various investment avenues in Capital Market with special reference to Derivatives. Journal of Contemporary Research in Management, (2), 101-112.

Management Studies, 1 (4), 83-94.

Wood, R., \& Zaichkowsky, J.L. (2004). Attitude and trading behavior of Stock Market Investors: A Segmentation Approach. Journal of Behavioral Finance, 5 (3), 170-

Tripathy, G. (2014). An Empirical 179. Investigation of Investors Perception towards Derivative Trading. Global Journal of Finance and Management, 6 (9), 99-104.

Sankar, S., \& Maran, K. (2013). Market Trading in India - Customer Perception. International Journal of Engineering and Management Research, 3 (2), 1-13.

Shafi, M. (2014). Determinants influencing individual investor behavior in stock market: a cross country research survey. Arabian Journal of Business and Management Review (Nigerian Chapter), 2 (1), 60-71.

Shukla, R.K., \& Upadhyaya, A. (2013). Determinants of Customers' Satisfaction for Stock Broking Services - An Empirical Analysis. Pacific Business Review International, 5 (7), 74-83.

Sultana, T.S., \& Pardhasaradhi, S. (2012). An Empirical Analysis of Factors Influencing Indian Individual Equity Investors' Decision Making and Behavior. European Journal of Business and Management, 4 (18), 50-61.

Stulz, R.M. (2004). Should We Fear Derivatives? Journal of Economic Perspectives, 18 (3), 173-192.

Vaddadi, K.M., \& Pratima, M. (2016). Investor's Attitude towards Adoption of Online Trading: (A Study on Online Investors Behavior in Visakhapatnam City). Asian Journal of Research in Business Economics and Management, 6 (2), 12-31.

Vignesh, K., \& Lawrence, A.R. (2016). A study on the awareness of derivatives among Retail investors in Trichy. International 